\title{
Faidherbia albida (Delile) Tree Dieback Effects on Crop Production in the Parkland Agroforests of Southwestern Niger
}

\author{
Abasse Tougiani, ${ }^{1}$ Moussa Massaoudou $\mathbb{D}^{1},{ }^{1}$ Adamou Haougui, ${ }^{1}$ Amadou Laouali, ${ }^{1}$ \\ and John C. Weber ${ }^{2}$ \\ ${ }^{1}$ Département de Gestion des Ressources Naturelles, Institut National de La Recherche Agronomique (INRAN), \\ BP 240 Maradi, Niger \\ ${ }^{2}$ World Agroforestry Centre (ICRAF), Lima, Peru \\ Correspondence should be addressed to Moussa Massaoudou; mmassaoudou13@gmail.com
}

Received 4 September 2020; Revised 12 January 2021; Accepted 27 January 2021; Published 10 February 2021

Academic Editor: Ignacio Garc a Gonz lez

Copyright ( $) 2021$ Abasse Tougiani et al. This is an open access article distributed under the Creative Commons Attribution License, which permits unrestricted use, distribution, and reproduction in any medium, provided the original work is properly cited.

\begin{abstract}
Faidherbia albida is an agroforestry tree species playing important agroecological and socioeconomic roles in arid and semiarid zones in Africa. For many years, anthropogenic and abiotic stresses were considered as the main threats for the species in West African parkland agroforests. Considerable dieback has recently occurred in F. albida trees of parkland agroforests in central southwestern Niger, and the causes are unknown. The objectives of this study are to (i) investigate the magnitude of dieback of F. albida trees and (ii) assess local community perceptions of the effects of $F$. albida dieback on crop production. The health status and phenology of $213 \mathrm{~F}$. albida trees were observed in the area where the dieback is occurring. Similarly, a sample of 144 people, $86 \%$ of which were farmers, was surveyed. Dieback incidence of $F$. albida trees was $19 \%$, with mortality of $6 \%$. Large-diameter trees had greater dieback than small-diameter trees. The most affected parts of the tree were the branches at $54 \%$ and the trunks at $39 \%$. The populations noted a 33-55\% reduction in the yields of major crops. This dieback of F. albida trees poses a serious threat to the survival of rural communities. Further studies can be conducted to identify the cause or cause of the dieback to guide the suitable agroforestry parkland management strategies.
\end{abstract}

\section{Introduction}

F. albida, originally known as Acacia albida as named by Delile [1], belongs to the family of Fabaceae [2]. Under favourable conditions, F. albida can reach more than $30 \mathrm{~m}$ in height and $1.5 \mathrm{~m}$ in diameter at breast height. The crown is pyramidal when the tree is young and becomes hemispherical with age. The leaves are compound and bipinnate. F. albida is a widely distributed species in the arid and semiarid zones of Africa [3, 4]. Unlike most Sahelian woody species, F. albida is a reverse phenology species: it loses its leaves with the first rains of the season and regrows them during the dry season $[5,6]$. On the basis of seed analysis, Ibrahim et al. [7] highlighted three ecotypes of F. albida in Africa: the Sahelian ecotype, the South African ecotype, and the ecotype that overlaps between the two zones, particularly in Ethiopia. In the same ecological zone, F. albida has contrasting morphological and growth variability [8-12]. The trees have long been used traditionally in the principal agricultural production system in West Africa, known as parkland agroforest. F. albida is an excellent agroforestry species for its impact on improving soil carbon and soil fertility, increasing the activity of symbiotic microorganisms, and improving the yields and nutritional values of crops [3, 13-17]. Due to its deep root system in dune soils, the competition for superficial water and nutrient resources between this species and surrounding crops is very limited [11].

The F. albida parkland agroforests of central southwestern Niger were born from the intervention of forestry projects promoting the species beginning in 1981. Because of the numerous benefits of $F$. albida trees mentioned above, the projects have the common goal of increasing their density from 35 to 50 trees/ha based on the low-cost 
investments of farmer-managed natural regeneration (FMNR) and planting wherever possible. Conclusive results have been obtained, leading to the domination of the parklands by $F$. albida. For example, the yield of millet grown under foliage of $F$. albida trees was 1.78 times higher than the yield of comparable plots without these trees [18]. During the last several years, however, this species, which improves the well-being of these local communities, has experienced increasing pressure not linked to human exploitation, but to a dieback leading in most cases to the trees' mortality. Similar attacks leading to the mortality or dieback of both young and old F. albida trees in the 1990s were reported by [18].

Tree dieback can be defined as the expression of the immediate effects of acute stresses [19]. The causes of this dieback remain unknown. However, many studies have addressed the decline of trees in plantations, natural forests, and farms around the world. The causes are still debatable. Very often the most indexed causes have been folivores, infections, and abiotic stresses which can be linked mainly to climate or soils $[20,21]$. Rural tree dieback could be linked by factors such as global climate change, overuse of pesticides, heavy metals in soils, overuse of fertilizers, pathogens, and habitat fragmentation $[22,23]$. These factors have direct effects on the survival of symbiotic microorganisms (mycorrhizae) which play an important role in the life of trees. Based on all of these causes, theories and models of tree dieback have been developed [24-26]. The interaction between several factors including biotic, abiotic, and human makes the study of tree dieback very complex. Thus, in his spiral of tree dieback and mortality, modified by $[27,28]$, main groups of causes are presented as follows: (i) predisposition factors, namely, the tree genetics, the soil nutrient deficit, climatic variability, chemical, physical, and biological degradation of soils, and chronic attacks from pathogens and insects; (ii) incentive and contributing factors such as extreme climate, high soil toxicity, insect defoliation, and competition. The dieback of F. albida trees was most often observed in the Dogondoutchi department in Niger, especially in the villages of Kiéché Commune. There is an urgent need to understand the causes and implications of the dieback so that effective responses can be put in place. Long before, it would be necessary to understand the magnitude of this tree dieback in this complex of agroforest parklands. To contribute to this, we asked the following questions: what is the magnitude of dieback of F. albida trees in these parkland agroforests? What is the current perception by local communities of the effects of this dieback on the main crop yields in the area?

\section{Materials and Methods}

2.1. Sites. The study area is located at $13^{\circ} 28^{\prime} \mathrm{N}$ and $4^{\circ} 3^{\prime} \mathrm{E}$ with an elevation of $311 \mathrm{~m}$ [29], on the left bank of the Dallol Maouri, a broad fossil valley framed by sandstone and sometimes cuirassed plateaus [30]. It is an agricultural area par excellence. The climatic data provided by the national meteorology department of Niger were used to characterize the climate of the study area. The climate is of the Sahelian type, with an average annual rainfall of $540 \pm 98 \mathrm{~mm}$ and maximum and minimum average annual temperatures of $36.8^{\circ} \mathrm{C}$ and $23.2^{\circ} \mathrm{C}$, respectively. The rainy season typically lasts 3-4 months (June-September). The maximum and minimum average annual humidity are $59 \%$ and $34 \%$, respectively. The study area belongs to the continental terminal formation with a spatial and temporal variability of the phreatic aquifer. Piezometric fluctuations throughout the year range from $1 \mathrm{~m}$ to $9 \mathrm{~m} \mathrm{[31].} \mathrm{The} \mathrm{vegetation} \mathrm{is}$ dominated mainly by parkland agroforests long enriched by plantations of F. albida trees and the practice of FMNR [18]. The study sites were chosen following interviews with the officers of the Department of the Environment in Dogondoutchi and the Rural Municipality of Keché. This choice was also based on the presence of F. albida trees and the prevalence of dieback in the parkland agroforests. This information made it possible to compile a list of five villages (KalloMota, Ruda, Adoua, GarinPaydou, Tambo Gataw, and GarinDianta) suitable for the study and distributed in different geographical locations of the municipality.

Two methods were used: surveys of local communities and an inventory of the parkland agroforests of the selected sites.

2.2. Surveys. The surveys were conducted in two stages in July 2018. Group discussions were conducted in each village to capture the overall perception of the problem, and individual surveys were conducted to obtain quantitative data using random sampling. The group discussions were focused on (i) the importance and benefit of F. albida trees for local communities; (ii) the threats to F. albida trees; (iii) the causes of the mortality observed in F. albida trees; and (iv) the manifestations of tree dieback. Individual surveys took a random sample of 144 people from all villages of which $86 \%$ were farmers. The $14 \%$ are composed of pastoralists, traditional healers, blacksmiths, etc. due to the exploitation of F. albida for their various uses. The average age of those surveyed varied from 47 to 50 years, and all socioprofessional groups (level of education, primary and secondary activities, etc.) in each village were represented. The surveys also examined the effects of F. albida tree dieback on the yield of the main crops in the area. The questions asked included farmers' estimates of crop yields before and after the mortality of F. albida trees in the different farms of the parkland agroforests. The main crops were Pennisetum glaucum (millet), Sorghum bicolor (sorghum), Vigna unguiculata (cowpea), and Hibiscus sabdariffa (sorrel of Guinea). The yields of each crop were given in the local unit and then converted to the international unit $(\mathrm{kg} / \mathrm{ha})$. It was difficult for the respondents to evaluate the crop yield specifically in the area under the tree crown before and after the dieback. Thus, the evolution of the yield was reported at the farm scale of each respondent.

2.3. Inventory. The tree inventory was conducted in July 2018 to provide data on the distribution of woody species, including F. albida trees, the trees' current state of health, and the prevalence of dieback. The parkland agroforests of 
three of the five villages were inventoried. The two others were close to each other and therefore provided no variability. Radial sampling with transects from the village in the four geographical directions was used [32,33]. A total of 48 plots were installed with 16 plots per village. Square plots measuring $50 \mathrm{~m} \times 50 \mathrm{~m}$ were installed [34]. The distance between two plots was $300 \mathrm{~m}$. Within each plot, an exhaustive count of woody species was performed, including $F$. albida trees. For each $F$. albida tree, observations were made on the health status (healthy, sick, or dead) and phenology (leafing, flowering, or fruiting). It would be difficult by simple observation to dissociate diseased trees from healthy trees. For dead trees, several definitions have been reported in the literature [35]. However, for this study, we are retaining dead trees, including fallen or standing trees, when its aerial part (leaves, branches, and trunk) has dried out or at the limit is rotten while trees are sick or stressed when they suffer damage from biotic and/or abiotic agents [36] and show signs of drying out or attacks on at least one of its aerial parts [37]. Thus, observations were made on all sampled trees, and medium diameter trees were the most attacked (Figure 1). Samples of leaves, branches, and roots of attacked trees and soil near the roots were taken for laboratory analysis to detect possible pathogens. The results are not presented because they are not the subject of this article.

2.4. Data Analysis. The survey data were processed using an Excel spreadsheet and Minitab 16 software for descriptive statistics (means, standard deviations, and frequencies). The one-way ANOVA test was applied to determine the statistical significance of the evolution of crop yields according to the periods before and after the mortality of F. albida trees at $5 \%$ of significance. This test was used to address the heterogeneity and nonnormality constraints of the data and sample size [38]. Finally, the yield difference according to the two periods was reported in percent.

\section{Results}

3.1. Local Perceptions of the Importance of F. albida Trees. Farmers were unanimous that the presence of $F$. albida trees improves soils fertility, protects crops against wind erosion, and controls the movement of sand. The species is also an important source of animal feed; farmers estimated one F. albida tree produces, depending on its age, an annual average of $90 \mathrm{~kg}$ of fruit pods without succulent branches at a price of $14,565 \pm 2,383$ FCFA (equivalent to 24.27 U. S. dollars).

3.2. Magnitude of F. albida Tree Dieback. Observations on the health status of $F$. albida trees in parkland agroforest yielded $74 \%$ of healthy trees versus $19 \%$ sick and $6 \%$ dead but standing. About six F. albida trees per hectare were sick or dead but standing (Table 1; Figure 2).

3.3. Local Perceptions of Effects of F. albida Tree Dieback on Crop Yields. Populations have recognised the loss of tree populations over the past decade, and this issue is becoming increasingly important in the area. The dieback concerns only F. albida trees; this is also a function of age. According to the respondents, the yields of the main crops mentioned were affected by the dieback of $F$. albida trees in the area. In fact, the average yields in $\mathrm{kg} / \mathrm{ha}$ before the dieback were $386.21 \pm 8.92$, $634.65 \pm 34.90,161.11 \pm 11.64$, and $90.91 \pm 20.42$ for millet, cowpea, sorrel of Guinea, and sorghum, respectively. Following the dieback, yields experienced a drastic reduction ranging from $33.03 \%$ to $55.47 \%$ (Table 2 ).

\section{Discussion}

The parkland agroforests of $F$. albida in Dogondoutchi were born out of the will to face the major challenges of environmental protection and the improvement of agricultural production. The last one remains a challenge in Niger due to significant population growth (3.6\%), food, and nutritional insecurity, the drop-in yield as a result of the decline in soil fertility, and parasitic pressures. Developing agroforest parklands where trees provide soil protection and fertilization remain necessary for the sustainability of the system. Significant investments have been made through development projects since the 1980s to increase the density of F. albida trees from 35 to 50 trees per hectare in the area [18]. The local populations agree that $F$. albida trees have significant positive effects on soil fertility, fodder for animals, and crop yields. A meta-analysis showed significant improvements in soil organic carbon ( $46 \%$ increase), total nitrogen (50\% increase), phosphorus (21\% increase), potassium (32\% increase), and yields of maize and sorghum (150\% and $73 \%$, respectively) under forest cover relative to the dryland zone [16]. In Niger, [14] reported an improvement in millet yield of $36 \%$ under $F$. albida trees. This is consistent with farmers' perceptions in this study: they observed a fall in their crop yields of between 33\% and 55\%, depending on the crop, with the mortality and the disappearance of $F$. albida trees.

In general, tree dieback has been addressed in many studies and causal links have been discussed [24, 25, 26, 39]. In the present study, F. albida trees most affected by dieback are those with large and medium diameters at breast height and with a density of less than 6 trees/ha. Does this mean that the dieback would be linked to the age of the tree? This statement is difficult to accept, but not to exclude, because in F. albida, the size of the tree is not necessarily related to age [40]. Physiologically, this could be explained by the fact that, in arid areas, when woody species are stressed, a trade-off emerges between safety and efficiency. The tree tends to favour its survival functions to the detriment of that of growth or reproduction by eliminating leaves, small twigs, and at worst that of large twigs and trunk [37, 40]. The most affected parts of the tree were branches at 54\% and trunks at $39 \%$ of cases. One of the direct consequences of this dieback on local communities was a reduction in the provision of ecosystem services by these parkland agroforests. The most striking aspect was the yield reduction in the area, which ranged from $33 \%$ to $55 \%$, depending on the crop (Table 2). This decline was attributable to the reduction in the nutrient cycling that $F$. albida trees provide. 


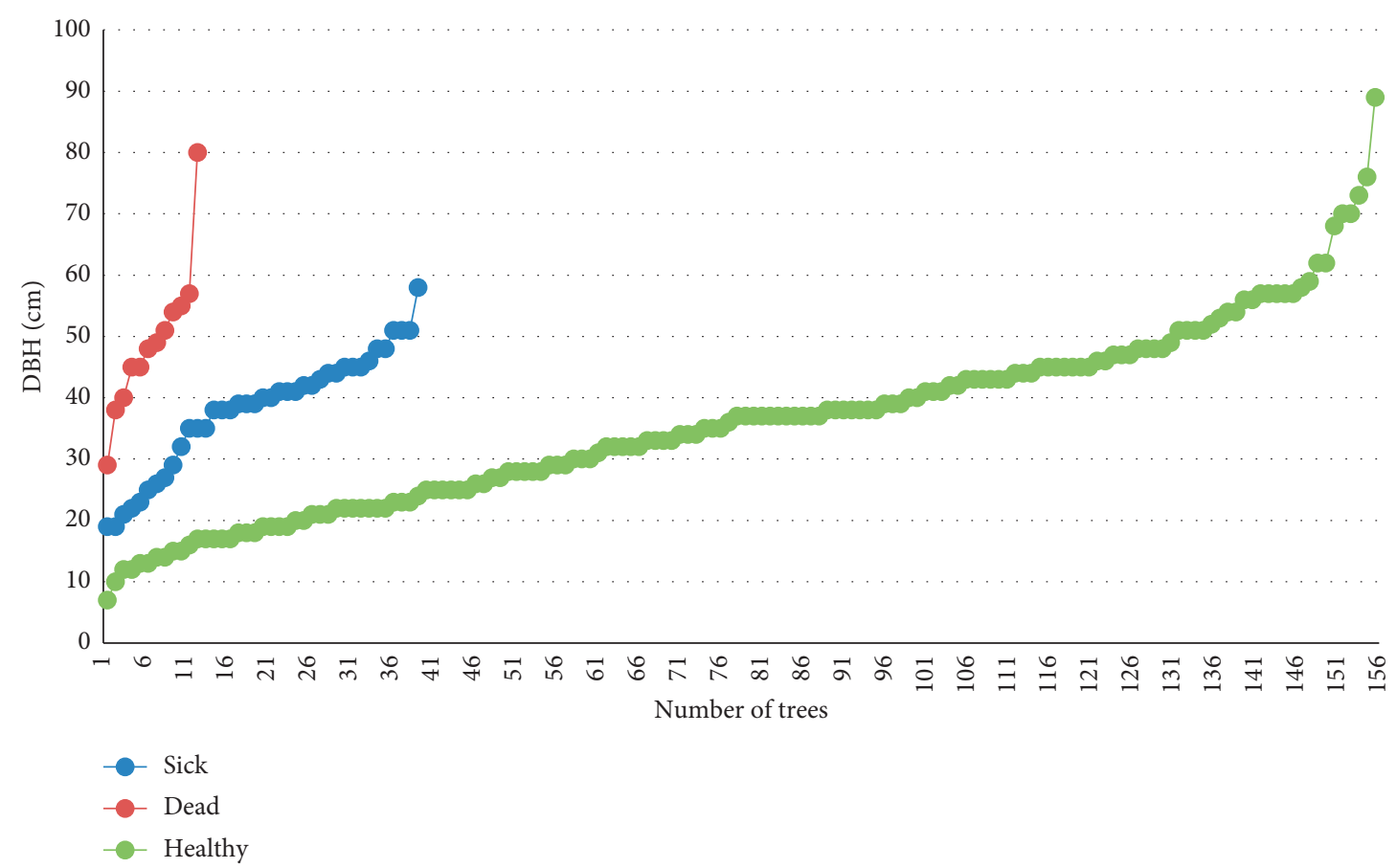

FIgURE 1: Distribution of health status of F. albida trees according to DBH.

TABLE 1: Distribution of the health status of F. albida trees.

\begin{tabular}{lcc}
\hline Health status & Frequency (\%) & Density (trees/ha) \\
\hline Healthy & 73.6 & 19.5 \\
Attacked & 18.9 & 5.0 \\
Cut & 1.4 & 0.4 \\
Leaning & 0.5 & 0.1 \\
Dead & 5.7 & 1.5 \\
Total & 100 & 26.5 \\
\hline
\end{tabular}

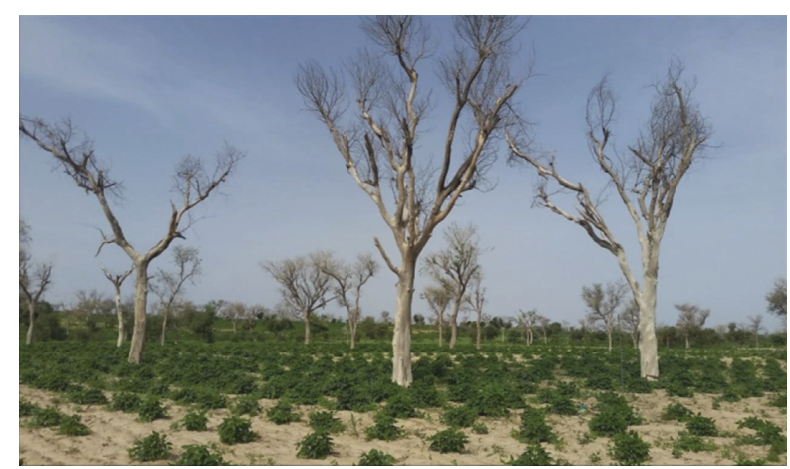

Figure 2: Dead trees of F. albida in a cowpea field in the commune of Kiéché.

According to the perceptions mentioned by the local communities in our study area, there are three main causes of mortality of F. albida: defoliating caterpillars, the larvae of beetles that were found in the trunks of dead trees, and rising groundwater. These causes are easily compared with those evoked in the spiral of $[26,38]$ which gives a general theoretical framework where all the plausible causes have been evoked with complex links leading to dieback and death of trees. This complexity lies in the interaction between biotic (bacteria, fungi, viruses, etc.), abiotic (climatic variability, soils, water stress, etc.), and human factors (modes of landscape occupations, tree management, etc.) $[20,21]$. The causes mentioned by the populations related exclusively to pest and disease part factors of the spiral. Analyzing these causes given by the populations shows them to be merely visual symptoms of the causes, but positive or negative interactions are created among the different living beings (e.g., microorganisms and trees) that are at times invisible to the naked eye. Symbiotic interactions favourable to tree species including $F$. albida canopies have been demonstrated [13]. On the other hand, those leading to the mortality of tree species have also been reported. For example, Fusarium solani has been reported in Acacia nilotica in Pakistan [41]. Similarly, a fungus named Pseudolagarobasidiumacaciicola has been identified as the causal agent of the $100 \%$ Acacia cyclops stand mortality in South Africa [42]. On the other hand, studies carried out in Namibia showed a mortality of F. albida trees of $51 \%$ of the stand, which was linked to the variation in the flow of water and the presence of invasive Prosopis species [43]. The first cause corroborates the statements of the local populations of our study area, while the second does not fit because F. albida is the dominant species and coexists with native tree species (not exotic, invasive Prosopis species) at the three sites. On the other hand, the authors in [4] have reported the presence of nematodes and defoliating caterpillars causing the mortality, especially of F. albida trees. Ultimately, all avenues must be explored to better detect the disease and/or pest of this species in the study area. 
TABLe 2: The effects of $F$. albida trees dieback on grain yields of main crops.

\begin{tabular}{lcccccc}
\hline Crops & $\mathrm{N}$ & Area of farms & Yield before dieback $(\mathrm{kg} / \mathrm{ha})$ & Yield with dieback $(\mathrm{kg} / \mathrm{ha})$ & Yield reduction $(\%)$ & $P$ value \\
\hline Millet & 150 & $5.17 \pm 6.58$ & $386.21 \pm 8.92 \mathrm{a}$ & $241.81 \pm 6.38 \mathrm{~b}$ & $33.03 \pm 3.32$ \\
Cowpea & 148 & $5.16 \pm 6.62$ & $634.65 \pm 34.90 \mathrm{a}$ & $334.55 \pm 19.75 \mathrm{~b}$ & $47.84 \pm 1.05$ \\
Sorrel of Guinea & 54 & $6.80 \pm 8.25$ & $161.11 \pm 11.64 \mathrm{a}$ & $75.37 \pm 7.02 \mathrm{~b}$ & $<0.01$ \\
Sorghum & 99 & $5.32 \pm 6.30$ & $90.91 \pm 20.42 \mathrm{a}$ & $39.36 \pm 9.37 \mathrm{~b}$ & $52.09 \pm 2.028$ & $<0.01$ \\
\hline
\end{tabular}

$\mathrm{N}$ is the number of respondents. The means for yield of each crop before and with dieback followed by different letters are statistically different $(P<0.05)$.

Hence, there is a need to take seriously the problem of dieback to avoid its expansion towards other ecological zones, because $F$. albida is an important agroforestry species with a wide distribution in the dryland zones of Africa [44].

\section{Conclusions}

This study has shown that the parkland agroforests of Dogondoutchi, dominated by F. albida trees, were affected by the dieback. The F. albida trees were wasting away, with an infestation rate of $19 \%$ and a mortality rate of $6 \%$. The causes of this dieback are scientifically unknown. According to local communities, this dieback reduced the yields of their main crops by between 33\% and $55 \%$. To explore also the causes of the dieback of F. albida trees, it is important to take into account the causal links presented by [27]. This involves analyzing samples taken from parts of infested trees to isolate the presence of biotic factors, soil samples for the plausible presence of heavy metals, or nematodes. This study provides field information on the current dynamics in the parkland agroforests of central southwest Niger. This information can be used (i) for famers to make efforts to ensure the regeneration of this species in their parkland agroforest and (ii) for scientists to conduct in-depth studies to identify the real causes of mortality of F. albida, whose large trees are regularly attacked, to test and identify plausible solutions in collaboration with local communities.

\section{Data Availability}

The data used to support the findings of this study cannot be shared because they are confidential.

\section{Conflicts of Interest}

The authors declare that they have no conflicts of interest.

\section{Acknowledgments}

The authors of this article thank the World Resources Institute for the financial support which made it possible to carry out the survey, the Ministry of the Environment of Niger which is the focal point of this study, and the General Directors of the Plant Protection, who provided technical support and facilitated the analysis of samples of the attacked organs.

\section{References}

[1] P. J. Wood, "The botany and distribution of Faidherbia albida, in West African semi-arid tropics," in Proceedings of the Workshop, R. J. Vandenbeldt, (Ed.), International Crops Research Institute for the Semi-Arid Tropics, International Centre for Research in Agroforestry, Niamey, Niger, April 1992.

[2] APGIII (Angiosperm Phylogeny Group), "An update of the Angiosperm Phylogeny Group classification for the orders and families of flowering plants: apg III," Botanical Journal of the Linnean Society, vol. 161, no. 2, pp. 105-121, 2009.

[3] P. Danthu, B. Hane, P. Sagna, and Y. K. Gassama, "Restoration of rooting competence in mature Faidherbiaalbida, a Sahelian leguminous tree, through serial root sucker micrografting," New Forests, vol. 24, no. 3, pp. 239-244, 2002.

[4] N. C. Mokgolodi, M. P. Setshogo, L.-l. Shi, Y.-j. Liu, and C. Ma, "Achieving food and nutritional security through agroforestry: a case of Faidherbia albida in sub-Saharan Africa," Forestry Studies in China, vol. 13, no. 2, pp. 123-131, 2011.

[5] Y. K. Gassama-Dia, D. Sané, and M. N’Doye, "Reproductive biology of faidherbiaalbida (del.) A," Chev. Silva Fennica, vol. 37, no. 4, pp. 429-436, 2003.

[6] O. Roupsard, A. Ferhi, A. Granier et al., "Reverse phenology and dry-season water uptake byFaidherbia albida (Del.) A. Chev. in an agroforestry parkland of Sudanese west Africa," Functional Ecology, vol. 13, no. 4, pp. 460-472, 2002.

[7] A. M. Ibrahim, C. W. Fagg, and S. A. Harris, "Seed and seedling variation amongst provenances in Faidherbia albida," Forest Ecology and Management,vol. 97, pp. 197-205, 1997.

[8] O. G. Dangasuk, P. Seurei, and S. Gudu, "Genetic variation in seed and seedling traits in 12 african provenances of faidherbiaalbida (del) A. Chev. At lodwar, Kenya. Agrofor syst 37," Agroforestry Systems, vol. 37, no. 2, pp. 133-141, 1997.

[9] C. Fredrick, C. Muthuri, K. Ngamau, and F. Sinclair, "Provenance variation in seed morphological characteristics, germination and early seedling growth of Faidherbiaalbida," Journal of Horticulture and Forestry, vol. 7, no. 5, pp. 127-140, 2015.

[10] A. Gachuiri, C. Muthuri, J. K. Muriuki, R. H. Jamnadass, and F. Sinclair, "Variations in shoot and root growth of three provenances of Faidherbia albida in clay and sand soil," Journal of Forestry Research, vol. 27, no. 1, pp. 59-66, 2016.

[11] O. Roupsard, H. I. Joly, and E. Dreyer, "Variability of initial growth, water-use efficiency and carbon isotope discrimination in seedlings of Faidherbia albida (Del.) A. Chev., a multipurpose tree of semi-arid Africa. Provenance and drought effects," Annales des Sciences Forestières, vol. 55, no. 3, pp. 329-348, 1998.

[12] M. Moussa, L. Mahamane, A. Gebrekirstos, and T. Abasse, "Wood anatomy and response to climate variability of faidherbiaalbida and prosopis africana using dendrochronology in the sahelian agroforestry parklands," in Agroforestry for 
Degraded Landscapes, J. C. Dagar, S. R. Gupta, and D. Teketay, Eds., Springer, Singapore, 2020.

[13] Z. Gnankambary, U. Ilstedt, G. Nyberg, V. Hien, and A. Malmer, "Nitrogen and phosphorus limitation of soil microbial respiration in two tropical parkland agroforests in the south-Sudanese zone of Burkina Faso: the effects of tree canopy and fertilization," Soil Biology and Biochemistry, vol. 40, pp. 350-359, 2009.

[14] R. M. Kho, B. Yacouba, M. Yayé et al., "Separating the effects of trees on crops: the case of Faidherbiaalbida and millet in Niger," Agroforestry Systems, vol. 52, no. 3, pp. 219-238, 2001.

[15] F. Faye, T. Krasova-Wade, M. Thiao et al., "Controlled ectomycorrhization of an exotic legume tree species Acacia holosericea affects the structure of root nodule bacteria community and their symbiotic effectiveness on Faidherbia albida, a native Sahelian Acacia," Soil Biology and Biochemistry, vol. 41, no. 6, pp. 1245-1252, 2009.

[16] G. W. Sileshi, "The magnitude and spatial extent of influence of Faidherbia albida trees on soil properties and primary productivity in drylands," Journal of Arid Environments, vol. 132, pp. 1-14, 2016.

[17] A. Takimoto, V. D. Nair, and P. K. R. Nair, "Contribution of trees to soil carbon sequestration under agroforestry systems in the West African Sahel," Agroforestry Systems, vol. 76, no. 1, pp. 11-25, 2008.

[18] J. T. Thomson, Schéma d'analyse des incitations institutionnelles dans le domaine de la foresterie communautaire, FAO, Rome, Italy, 1994.

[19] V. Jurskis, "Eucalypt decline in Australia, and a general concept of tree decline and dieback," Forest Ecology and Management, vol. 215, no. 1-3, pp. 1-20, 2005.

[20] P. Gonzalez, C. J. Tucker, and H. Sy, "Tree density and species decline in the African Sahel attributable to climate," Journal of Arid Environments, vol. 78, pp. 55-64, 2012.

[21] T. Paap, N. C. Brouwers, T. I. Burgess et al., "Importance of climate, anthropogenic disturbance and pathogens (Quambalariacoyrecup and Phytophthora spp.) on marri (Corymbiacalophylla) tree health in southwest Western Australia," Annals of Forest Science, vol. 74, p. 62, 2017.

[22] D. C. Close and N. J. Davidson, "Review of rural tree declinein a changing Australian climate," Tasforests, vol. 15, pp. 1-18, 2004.

[23] S. J. Sapsford, T. Paap, G. E. S. J. Hardy, and T. I. Burgess, "The "chicken or the egg": which comes first, forest tree decline or loss of mycorrhizae?" Plant Ecology, vol. 218, no. 9, pp. 1093-1106, 2017.

[24] J. Fischer, A. Zerger, P. Gibbons, J. Stott, and B. S. Law, "Tree decline and the future of Australian farmland biodiversity," Proceedings of the National Academy of Sciences, vol. 107, no. 45, pp. 19597-19602, 2010.

[25] K. Sherren, J. Fischer, H. Clayton, A. Hauldren, and S. Dovers, "Lessons from visualising the landscape and habitat implications of tree decline-and its remediation through tree planting-in Australia's grazing landscapes," Landscape and Urban Planning, vol. 103, no. 2, pp. 248-258, 2011.

[26] G. Whyte, K. Howard, G. E. S. J. Hardy, and T. I. Burgess, "The Tree Decline Recovery Seesaw; a conceptual model of the decline and recovery of drought stressedplantation trees," Forest Ecology and Management, vol. 370, pp. 102-113, 2016.

[27] P. D. Manion, Tree Disease Concepts, Prentice Hall, Englewood Cliffs, NJ, USA, 2nd edition, 1991.

[28] R. Mrkva, "Ochranalesa: ekologické pojetí a rozvoj [Forest protection. Ecological conception and development]," Lesnictví-Forestry, vol. 39, pp. 357-364, 1993.
[29] J. C. Weber and C. Sotelo Montes, "Correlations and clines in tree growth and wood density of Balanites aegyptiaca (L.) Delile provenances in Niger," New Forests, vol. 39, no. 1, pp. 39-49, 2010.

[30] G. Jean-Michel, H. Bernard, and R. René, "Dogondoutchi, petit centre urbain du Niger," Journal Alp Res/RévGéo Alp, vol. 56, no. 2, pp. 297-358, 1968.

[31] B. LeducC and S. P. John, "Water table fluctuation and recharge in semi-arid climate: some results of the HAPEX-Sahel hydrodynamic survey (Niger)," Journal of Hydrology, vol. 188189, pp. 123-138, 1997.

[32] M. Badji, D. Sanogo, and L. E. Akpo, "Dynamique de la végétation ligneuse des espaces sylvo-pastoraux villageois mis en défens dans le Sud du Bassin arachidier au Sénégal," Bois For Trop, vol. 319, no. 1, pp. 43-52, 2014.

[33] M. Larwanou and M. Saâdou, "The role of human interventions in tree dynamics and environmental rehabilitation in the Sahel zone of Niger," Journal of Arid Environments, vol. 75, no. 2, pp. 194-200, 2011.

[34] A. Thiombiano, K. R. Glélé, P. Bayen, J. I. Boussim, and A. Mahamane, "Méthodes et dispositifs d'inventaires forestiers en Afrique de l'Ouest: état des lieux et propositions pour une harmonisation," Artificial Neural Network Science Agriculture, vol. 19, pp. 15-23, 2015.

[35] J. Rondeux and C. Sanchez, "Review of indicators and field methods for monitoring biodiversity within national forest inventories," Core Variable: Deadwood. Environ Monit Assess, vol. 164, pp. 617-630, 2012.

[36] R. D. Weir, M. Phinney, and E. C. Lofroth, "Big, sick, and rotting: why tree size, damage, and decay are important to Fisher reproductive habitat," Forest Ecology and Management, vol. 265, pp. 230-240, 2012.

[37] S. M. Gleason, M. Westoby, S. Jansen et al., "Weak tradeoff between xylem safety and xylem-specific hydraulic efficiency across the world's woody plant species," New Phytologist, vol. 209, no. 1, pp. 123-136, 2016.

[38] R. Rakotomalala, "Comparaison de populations Tests paramétriques. Version 1.2," Université Lumière Lyon, vol. 2, p. 109, 2013.

[39] J. Holuša, "Health condition of Norway spruce Picea abies (L.) Karst. stands in the Beskid Mts," Dendrobiology, vol. 51, pp. 11-15, 2004.

[40] M. Moussa, A. Tougiani, R. Habou, and M. Larwanou, "Seasonal variation and modeling of leaf area growth in Jatropha curcas L. plants: implication for understanding the species adaptation in the Sahel of Niger," African Journal of Plant Science, vol. 14, no. 6, pp. 205-212, 2020.

[41] A. Javaid and N. Akhtar, "Kikar (Acacia nilotica) dieback in the Punjab, Pakistan," Pakistan Journal of Phytopathology, vol. 18 , no. 2, pp. 161-165, 2006.

[42] D. Ward and C. Rohner, "Anthropogenic causes of high mortality and low recruitment in three Acacia tree taxa in the Negev desert, Israel," Biodiversity and Conservation, vol. 6, no. 6 , pp. $877-893,1997$.

[43] C. M. S. Douglas, M. Mulligan, X. A. Harrison, J. R. Henschel, N. Pettorelli, and G. Cowlishaw, "Widespread dieback of riparian trees on a dammed ephemeral river and evidence of local mitigation by tributary flows," PeerJ, vol. 4, p. e2622, 2016.

[44] F. Garrity, K. Akinnifesi, O. C. Ajayi et al., "Evergreen Agriculture: a robust approach to sustainable food security in Africa," Food Secu, vol. 2, pp. 197-214, 2016. 